\title{
MSH6 Negative
}

National Cancer Institute

\section{Source}

National Cancer Institute. MSH6 Negative. NCI Thesaurus. Code C162309.

An indication that expression of MSH6 has not been detected in a sample. 